\title{
The eurozone financial crisis: debt, credit ratings and monetary and fiscal policy
}

\author{
Michael Wickens ${ }^{1}$
}

Published online: 19 April 2016

(C) The Author(s) 2016. This article is published with open access at Springerlink.com

\begin{abstract}
This paper discusses the eurozone financial crisis. It argues that it was largely the result of a common monetary policy not being suitable for individual countries which led to excessive private and public borrowing and a debt crisis. Neither borrowing rates nor credit ratings anticipated the crisis. Fundamental changes to eurozone governance are being proposed. The paper examines whether instead there might be a market solution if financial markets priced risk better. Accordingly, a more timely way of obtaining credit ratings is shown.
\end{abstract}

Keywords Monetary policy - Fiscal policy · Eurozone financial crisis · Credit ratings

JEL Classification $\quad \mathrm{E} 62 \cdot \mathrm{H} 30 \cdot \mathrm{H} 60$

\section{Introduction}

Since 2007 eurozone countries have been in a constant state of economic crisis: all countries have experienced low growth rates; some have had negative growth and massive unemployment, especially youth unemployment; some countries have had financial crises with unsustainable private and public debts and sky-high borrowing rates; Greece is in danger of having to leave the euro in order to survive; even the continued existence of the euro itself has been called into question. All of this has caused huge political and social upheavals. Countries have been in conflict over the appropriate policies to adopt; new anti-austerity political parties have ousted

Michael Wickens

mike.wickens@york.ac.uk

1 CEPR and CESifo, Cardiff Business School, University of York, York, UK 
traditional parties; immigration has lept as people have searched for work which has raised social tensions everywhere.

None of this was envisaged when the euro was introduced in 1999 yet, as argued in this paper, its introduction is the source of the crisis. The paper explains why this is. It then considers how the euro might be saved. Current discussion has centred on greater central control of policy: having common fiscal as well as monetary policies, and even greater political integration through a more federal structure. This paper asks whether there might be a market solution that does not require more central control. At present the eurozone has a common monetary policy that enables all countries to borrow cheaply irrespective of risk, and does so even when the crisis has revealed the risks involved. The failure of markets to price risk correctly seems to be a major contributory factor. The market solution proposed to address the longterm problem simply requires borrowing rates to reflect the risks involved. (In the short term other measures are required.) The paper shows that this did not happen in the lead up to the crisis. As a result, both private and public borrowing were excessive, which led to the crisis.

In supporting these arguments this paper draws on a number of published technical articles of the author which examine individual aspects. The contribution of the current paper is to examine their implications for the eurozone crisis.

The paper is set out as follows. In Sect. 2 the origins of the eurozone crisis are examined and in Sect. 3 the policy implications are discussed. The puzzling failure of financial markets to correctly price credit risk prior to the crisis is examined in Sect. 4. In Sect. 5 an independent measure of credit risk for eurozone countries is described. Some conclusions are drawn in Sect. 6.

\section{Origins of the eurozone crisis}

The main aim in introducing the euro was to facilitate the development of a single market in goods and services by removing the transactions costs associated with foreign exchange through sharing a single currency. The problem, which was foreseen by many economists, was that the eurozone was not an optimal currency area having, for example, different fiscal stances, capital markets, labour laws and rates of inflation. This was downplayed in official circles as it was widely assumed that eurozone economies would rapidly converge, thereby creating an optimal currency area. Even more persuasive for countries facing high interest rates was the expectation that in future they would be able to borrow at much lower rates, such as those of Germany. This expectation was due to the way that the European Central Bank sets monetary policy: it targets a weighted average of eurozone inflation rates, where the weights reflect the size of the member economies. This entailed that Germany, being a large country with low inflation, would exert a strong influence on rates. These arrangements were a quid pro quo for the Bundesbank agreeing to set up the euro as it wanted a large say on the ECB's monetary policy.

Initial economic developments encouraged optimism of the success of the euro. Many countries found their borrowing costs were indeed much lower; real interest rates became negative in some countries. An update of the analysis of Wickens 
(2010) shows the growing problem of eurozone membership. Figure 1 shows the real rates of interest of selected eurozone countries-the crisis countries plus Germany. Although prior to the euro real interest rates were positive for each of these countries in 1998, during the period 2001-2007 real interest rates were negative with the exception of Germany which had positive real rates throughout this period.

Lower real interest rates encouraged greater private and public borrowing, which led to higher rates of economic growth. Figure 2 shows the growth of nominal GDP in eurozone countries over the period 1998-2013. For the period 1999-2007, the GDP of Ireland grew by $78 \%$, that of Greece by $44 \%$, and that of Spain by $39 \%$ while that of Germany only grew by $15 \%$.

This stimulus to economic activity caused price levels to rise sharply, especially in the countries with low real interest rates. Figure 3 shows the rise in the price level over the period 1998-2013. It reveals considerable dispersion. Thus, while the price level in Ireland increased over the period 1999-2008 by $41 \%$, that of Greece by $38 \%$, that of Portugal by $35 \%$ and that of Spain by $44 \%$, Germany's price level only increased by $9 \%$. This entailed a huge loss of competitiveness compared to Germany for the countries that would prove to be the main crisis countries of the eurozone.

The connection between low real interest rates and the stimulus this provided for economic activity and higher inflation is shown in Fig. 4 which plots the growth in the price level over the period 1999-2007 against the average real interest rate over that period for selected eurozone countries (Germany, Greece, Ireland, Italy, Portugal and Spain). The graph suggests that the lower the real interest rate, the higher is inflation.

This evidence shows that eurozone economies have diverged since the inception of the euro and have not converged as was predicted by most. Further evidence on

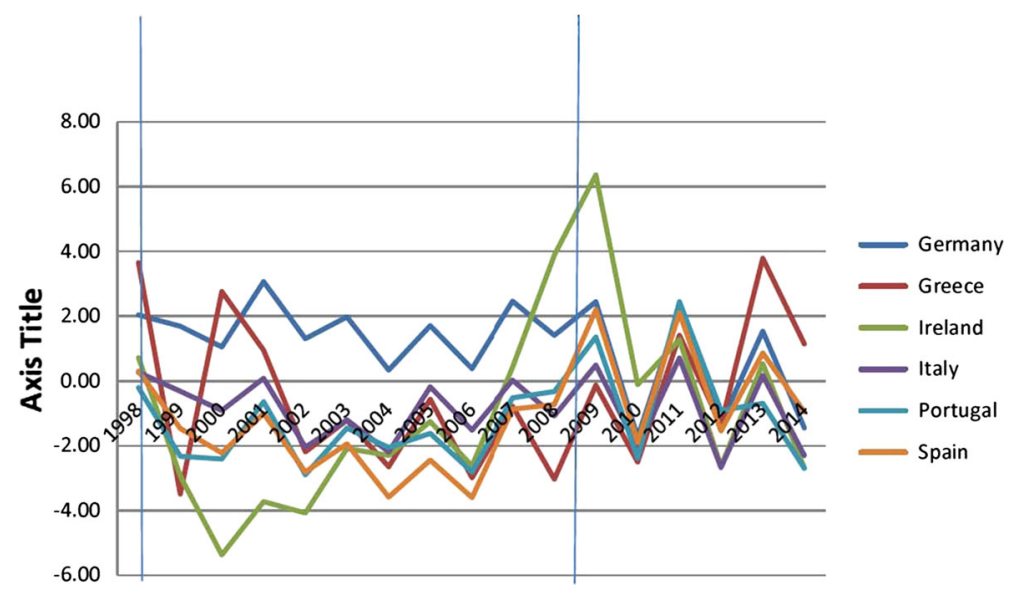

Fig. 1 Selected eurozone annual real interest rates 1988-2014 


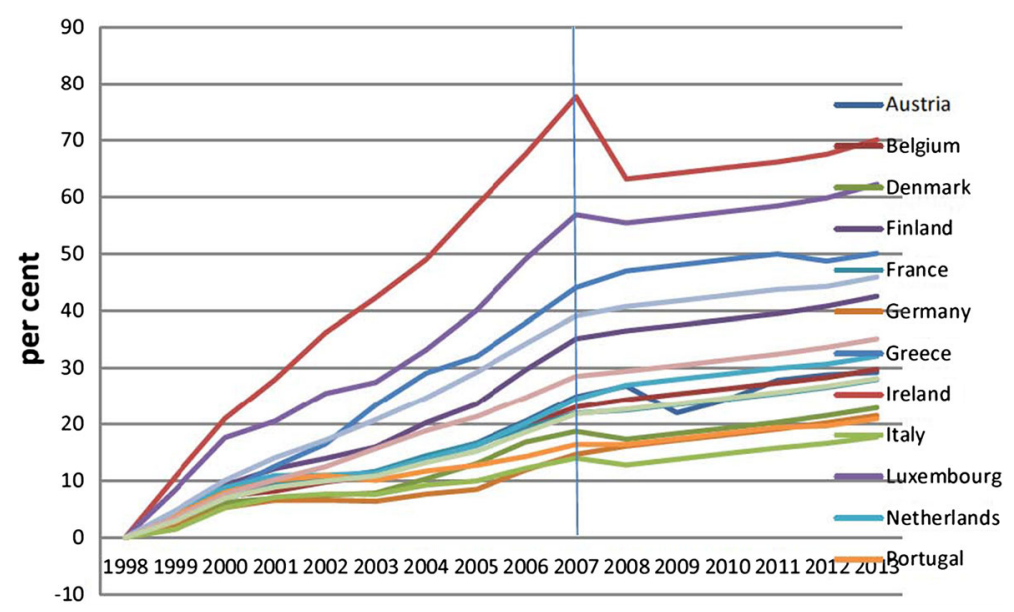

Fig. 2 Cumulative growth of eurozone nominal GDP 1988-2013

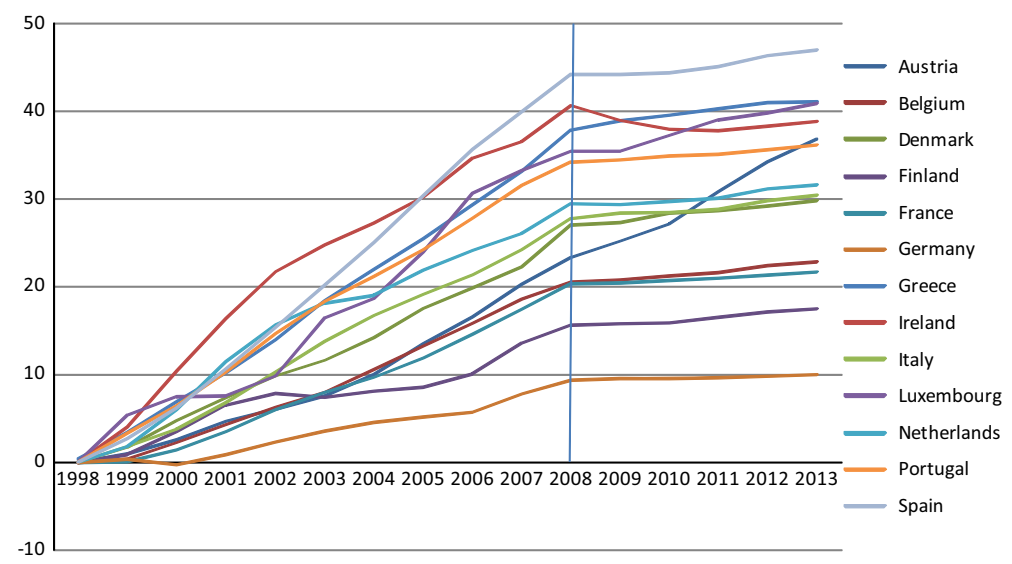

Fig. 3 Eurozone (log) price levels 1988-2013 [base P(1998) = 1]

the lack of convergence is provided by Fig. 5 which shows that the higher was inflation in 1999, the greater was inflation in the years prior to the financial crisis.

To summarise, this evidence provides strong support for the argument that since the inception of the euro, eurozone economies, far from converging as expected, had diverging output and price levels until 2007/2008 when the financial crisis intervened. Since then there has been little or no output growth and close to zero inflation. Crucially, as a result of joining the euro, the main crisis countries experienced negative real interest rates until the crisis and the highest rates of economic growth and loss of competitiveness. This was due to the (temporary) stimulus of excessive private and public sector borrowing in these countries which was fuelled by being able to borrow at negative, and much lower, real interest rates 


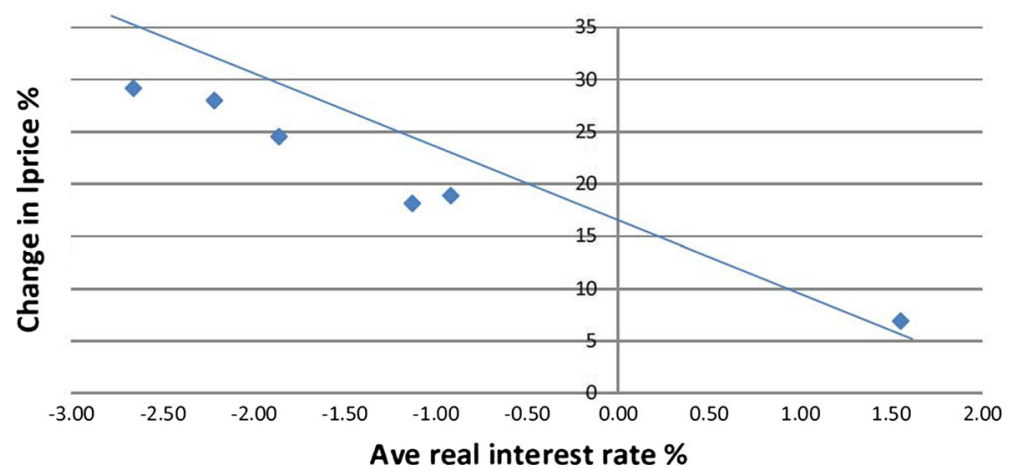

Fig. 4 Selected eurozone average real interest rates versus changed in the price level 1999-2007

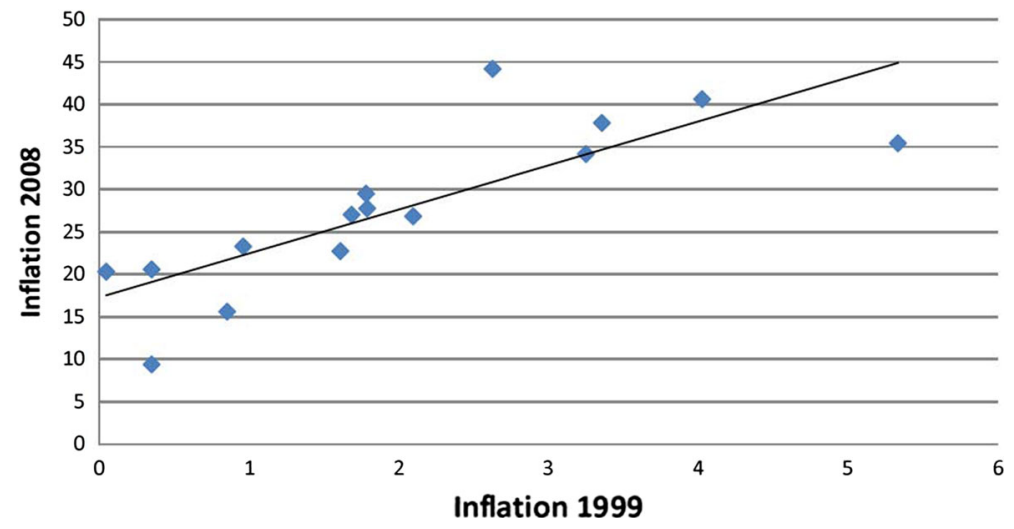

Fig. 5 Eurozone cumulative infection 2008 versus inflation level

than they faced prior to joining the euro. In contrast, countries such as Germany, due to having lower inflation rates prior to joining the euro, did not experience negative real interest rates and had both much lower growth and inflation thereafter. Germany also gained in competitiveness.

\section{The policy problems facing the eurozone}

From a longer-term perspective, the loss of competitiveness and much greater indebtedness are critical features as they are the most difficult to reverse in the short to medium term. They are also the main factors in causing the crisis, and they identify the key weaknesses in the euro system. There is also a symmetry in the problem that is often overlooked. The emphasis is commonly placed on heavily over-indebted countries which, because they borrow from abroad, typically have large current account deficits. But, as Keynes observed in the discussions surrounding the creation of the Bretton Woods system, the other side of the 
problem is how to prevent the build up of large current account surpluses. Thus the eurozone crisis has highlighted the problems of both Greece and Germany.

An essential feature of a successful economic system - and a missing ingredient in the euro system - is the ability to re-adjust an economy at low cost. The least-cost way of improving an economy's competitiveness is to depreciate its exchange rate. This is denied to eurozone countries as they have a fixed nominal exchange rate with each other. Instead, they have to resort to an internal depreciation achieved by lowering labour costs and prices. This has proved to be politically and socially extremely costly with high unemployment rates, especially for the young, and increased immigration. It has also led to the Target 2 problem.

Interestingly, under the Bretton Woods fixed exchange rate system, the UK continually faced a balance of payments of crisis. As soon as the economy began to grow, imports exceeded exports. Having assigned monetary policy to fixing the exchange rate, it was then necessary to tighten fiscal policy to restore current account balance. It was only when the Bretton Woods system broke down, and the UK allowed sterling to float, so that competitivenes could be maintained and this stop-go cycle eliminated.

As a result of the financial crisis and, in particular, the huge build-up of debt, both fiscal and monetary policy have been conducted in remarkably unconventional ways. Instead of the usual loosening of fiscal policy in recession, both in the eurozone and in other countries, such as the UK and the US, the fiscal stance has been tightened to avoid further accumulation of public debt. Moreover, instead of tightening monetary policy to discourage further excessive borrowing, monetary policy has been loosened to such an extent that interest rates became so close to their lower bound that conventional monetary policy of the last 20 years based on interest rates targeting inflation became inoperative and was replaced by quantity

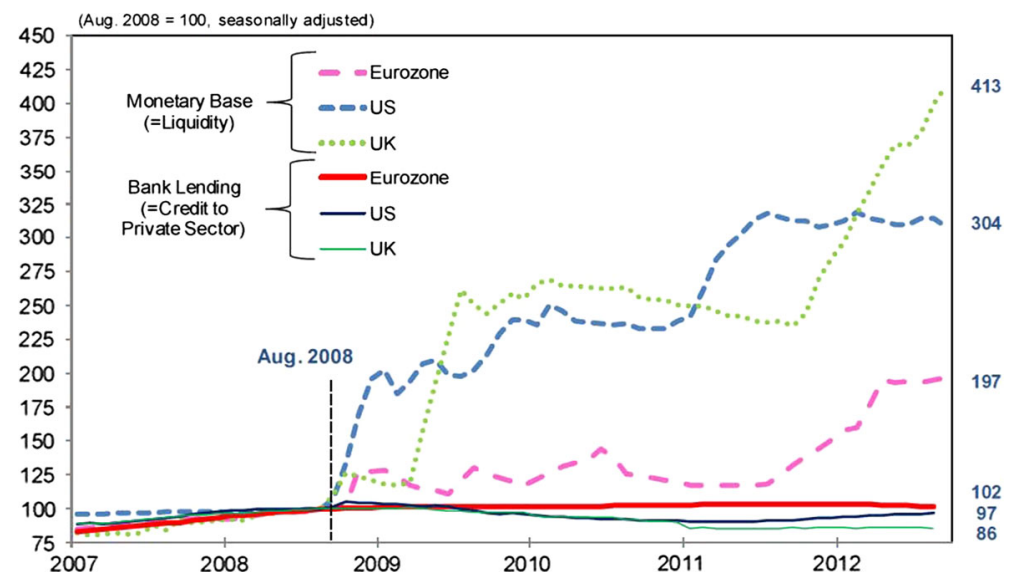

Fig. 6 Massive quantitative easings failed to increase credit to the private sector. (1) UK's reserve balaces data are seasonally unadjusted. (2) UK's bank lending data exclude intermediate financial institutions. (3) Base money's figures of eurozone are seasonally by Nomura Research Institute. Source: Nomura Research Institute, based on FRB, ECB and Bank of England data 
controls. The jury is still out on the effectiveness of these unconventional responses. The signs are not encouraging. Monetary policy, although reducing the cost of capital, does not appear to have stimulated investment. Instead, it appears to have distorted financial marketsm, causing a portfolio shift that has resulted in stockmarket booms, and has impoverished ordinary savers and pensioners through otherwise lowering savings rates.

Evidence on the failure of unconventional monetary policy to stimulate credit expansion in the eurozone, the UK and the US is provided in Fig. 6, which is taken from Koo (2011). It shows that although, as a result of quantitative easing, the monetary base has expanded hugely since 2008 in all three monetary jurisdictions, bank credit has, if anything, declined.

The financial difficulties of Greece have revealed more deep-seated flaws in the euro system. A key role of a central bank is to act as lender of last resort to the private banks. The European Central Bank has been politically constrained in carrying out this function. It even suspended support for the Greek banking system thereby bringing it to the point of collapse. Only a political agreement at heads of government level prevented this. One problem was that was unclear was whether Greek banks satisfied Bagehot's condition that a bank should be solvent in order to be bailed out. This depended on the market value of their large holdings of Greek government bonds and whether the Greek government would default on its debt. In this way the lender of last resort function of the ECB became tied to the solvency of the Greek state. This is largely a political issue related to the bigger problem of the rules that apply to eurozone countries on which there appears to be no agreement.

Article 105 of the Maastricht Treaty requires the ECB to maintain an average eurozone inflation rate not greater than $2 \%$ which it has successfully achieved. Article 127 of the Lisbon Treaty set out further responsibilities of the ECB. This Article requires any country leaving the eurozone to also leave the EU. But it does not set out rules governing country bailouts. Both articles imply that the ECB has responsibility only for monetary policy. However, it appears that in the financial crisis the ECB extended its reach to fiscal policy as it set out four fiscal reforms that Ireland had to undertake before receiving loans from the ECB.

The fiscal rules contained in the Stability and Growth Pact would, if adhered to, avoid the need for bailouts. Significantly, Germany and France were the first countries to break the rules. Contrary to the rules, they did so without penalty. The rules themselves impose a 60 percent limit on a government's debt-GDP ratio and a $3 \%$ limit on the ratio of the government deficit to GDP. Both of which have been exceeded since the financial crisis by most eurozone countries, especially by Greece. These limits imply that the fiscal stance would be permanently sustainable only with the additional condition that the nominal rate of growth exceeds $5 \%$. Since the financial crisis the rate of nominal growth of any eurozone country has rarely exceeded $5 \%$. Consequently, even the Maastricht conditions do not provide a viable rule.

Rules for a bailout remain to be determined by eurozone countries. Switzerland has a clear no-bailout condition for its cantons which it has adhered to. The eurozone has shown itself reluctant to impose a no-bailout rule due to concerns about the precedent this would set: once one country has left the euro the fear is that others may be more 
inclined to do so. At the same time the eurozone has failed to set rules determining the conditions for the write-down of loans. The results reported below strongly suggest that it is unlikely that the agreement reached in July 2015 will allow Greece to stay in the euro without a further substantial write-down of debt.

As a result of the eurozone financial crisis, a number of reforms to the institutional arrangements of the eurozone are under consideration: a banking union, a fiscal union and a more federal political structure. The aim of all three would be to share the burden of economic and financial distress more widely and to impose common rules on member countries. The banking union would aim to provide a larger and more mutualised bailout fund. A fiscal union would aim to integrate decisions on government expenditures and taxation with a view to controlling the size of budget deficits and fiscal transfers, and avoiding tax competition. Such reforms would increase the need for joint political supervision and hence a more federal structure.

To summarise, belonging to the eurozone seems to have been the primary cause of the financial crisis for many countries. Existing rules governing the eurozone failed to avert the financial crisis and it is far from clear whether the uncoventional fiscal and monetary policies implemented after the crisis have led to much improvement. Being in a fixed exchange rate system is highly likely to significantly increase the cost of adjustment following negative economic shocks. Deciding how best to rescue countries in severe financial difficulties has proved politically contentious. For example, Germany is concerned that the eurozone is becoming a transfer union. Nonetheless, in order to save monetary union, fiscal transfers between countries may be required. This may entail greater political integration and a banking and fiscal union which would also be contentious. For example, the French prime minister has recently said that France will decide its own budget. The alternative is a no-bailout rule entailing limited national fiscal autonomy. Having given up their monetary policy instrument, eurozone countries would then have also given up their independent fiscal policy instrument plus considerable political independence.

\section{Puzzling failure of financial markets to correctly price credit risk}

An intriguing feature of the financial crisis rarely, if ever, drawn attention to is the failure of financial markets prior to the crisis to correctly price credit risk. Had they done so perhaps the crisis in the US, the UK and the eurozone could have been avoided. And if they do so in the future, perhaps this will solve one of the fundamental problems of the eurozone, namely, the ability of the more profligate countries to borrow at the same rate as the more prudent countries. In this way it may be possible for the eurozone to survive without the need for greater political and fiscal integration. Even now the ECB, through its near zero repo rate and its burgeoning $\mathrm{QE}$ programme, is trying to drive down borrowing rates rather than have them reflect borrowing risks.

The recent academic literature on financial frictions is attempting to fill a gap in macro-finance by analysing the effect on interest rates of default, especially default 
in the inter-bank market, see for example Curdia and Woodford (2008) and Gertler and Kiyotaki (2010). The main result is that banks should charge a credit premium - an external finance premium — to borrowers that might default. An odd feature of this literature is the assumption that banks are risk neutral and the credit premium is in order that the expected return on the loan is the same when default is thought a possibility as when it is not. In other words, the external finance premium is not a risk premium.

Although the financial frictions literature may provide an explanation of the rise in borrowing rates following the financial crisis, and why the subsequent recession was so deep and prolonged, it does not explain the financial crisis as borrowing rates did not anticipate the crisis as envisaged in the financial frictions literature. Not only did spreads not increase prior to the financial crisis, nor were sovereign credit ratings downgraded. Evidence on the official credit ratings of eurozone countries over the period 1990-2012 is provided in Fig. 7. In short, financial markets failed to reflect the risks building up prior to the crisis which is evident in the graphs above.

Once the financial crisis began eurozone CDS prices started rising as shown in Fig. 8. Starting near zero at the start of 2008 for all eurozone countries, CDS prices rose in 2009, and again in 2011-2012 before falling in 2013. (Note the difference in scales across countries.) In contrast, credit ratings remained largely unaffected for most countries and only fell for the crisis countries in 2010 or 2011 . Even for Greece CDS prices did not rise much until 2010, which is when its credit rating started to be steadily downgraded.
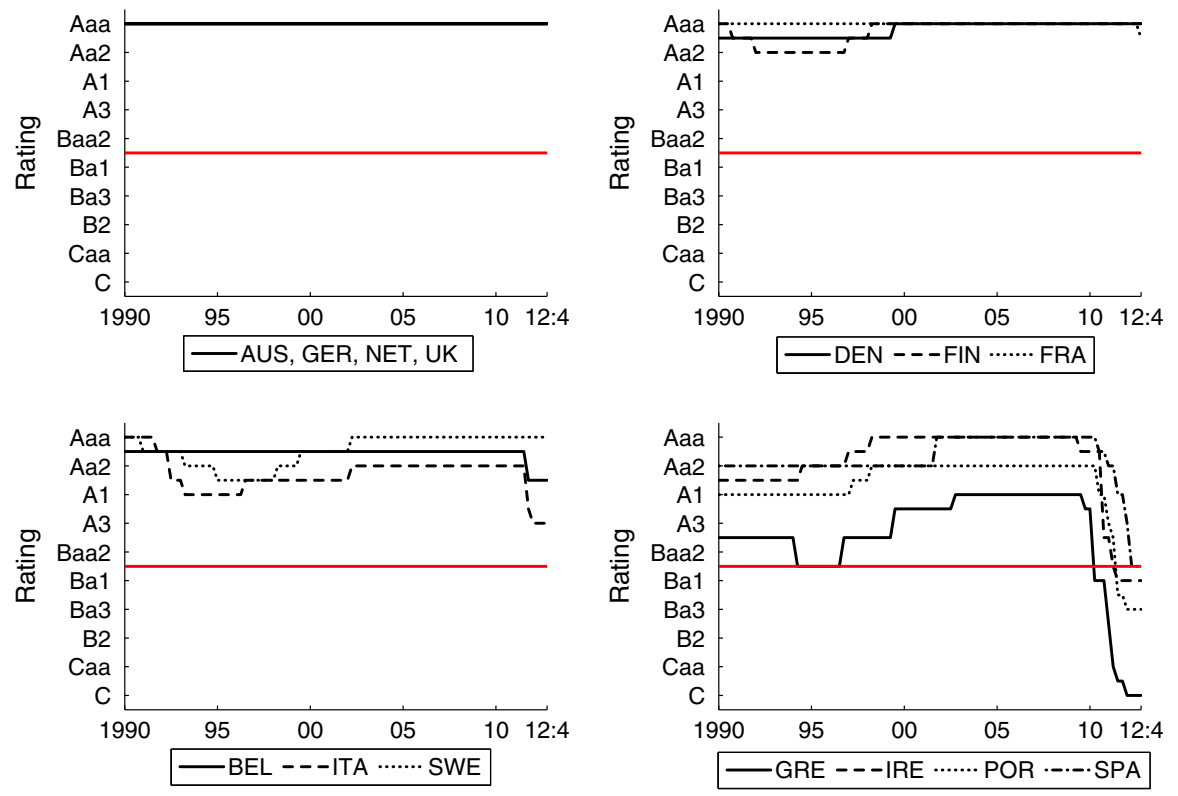

Fig. 7 Historic sovereign credit ratings 1990-2012 


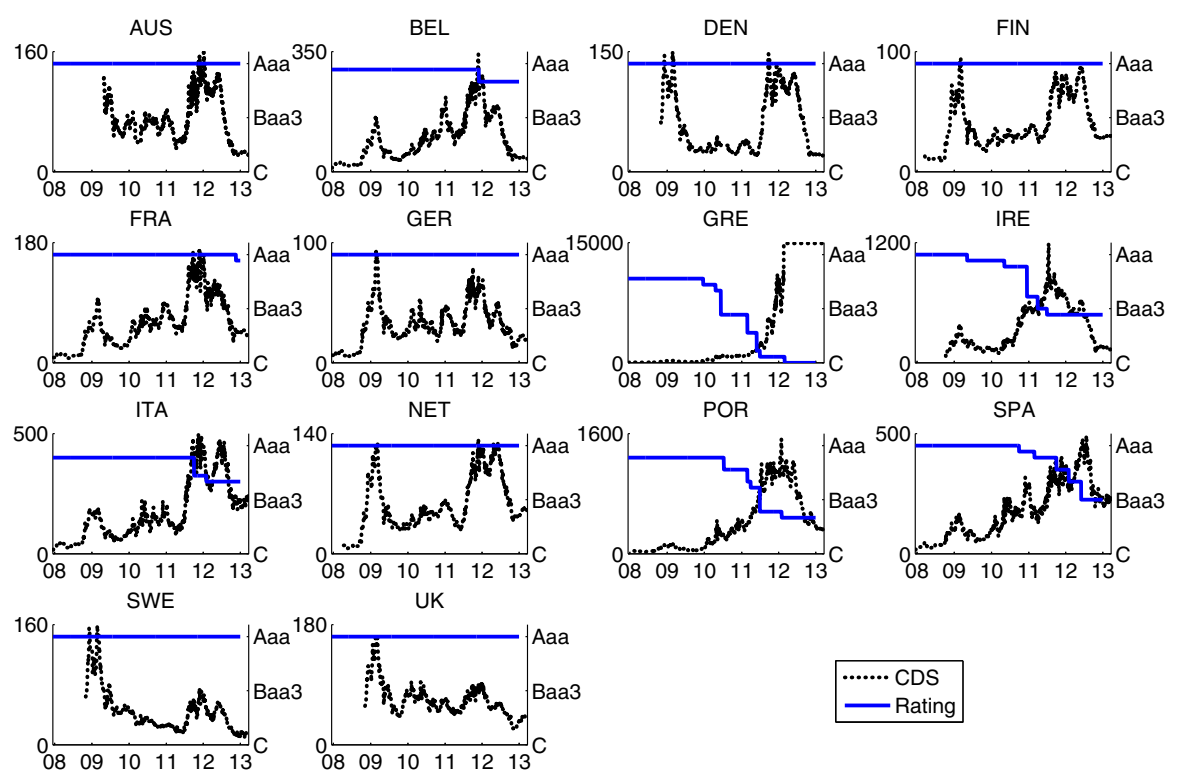

Fig. 8 Credit ratings and CDS prices 2007-2013

\section{Model-based credit ratings}

The failure of financial markets to anticipate the financial crisis suggests that they would not be capable of providing the corrective to the borrowing rates of individual economies that is required to offset the one-size-fits-all monetary policy of the eurozone and thereby obviate the growing pressure for fundamental reform. Although the ECB has criticised the performance of the credit rating agencies and has advocated an independent assessment of credit ratings, the cost of this has been regarded as prohibitive, see Polito and Wickens (2015).

The fundamental problem is to develop an early warning mechanism for possible fiscal distress. A key question is whether a country's fiscal stance is sustainable without policy changes. Most econometric studies of fiscal sustainability have focused on the time series properties of government deficits and debts and, in particular, whether they are stationary processes and not on an explosive trajectory, when they would be unsustainable. This is an entirely backward-looking assessment and, in the event of finding that the current stance is unsustainable, is open to the response that policy will be changed in the future so that the fiscal stance becomes sustainable. To make matters worse, in principle the policy change could be in the indefinite future. Given that financial markets are concerned about the short run as well as the long run, and about the future rather than the past, clearly this is not a practical way to assess the fiscal stance.

Polito and Wickens $(2011,2012,2015)$ suggested two alternative approaches that focus on the future rather than the past. The first two papers propose an index of the fiscal stance that assesses whether future expected primary surpluses are sufficient 
to meet current debt liabilities. The third paper focuses on the cost of financing expected future government debt liabilities by providing an independent assessment of sovereign credit ratings. This approach seems the more promising as it provides credit ratings that are much more timely than the official credit ratings. For example, downgrades were identified that either coincided with the onset of the financial crisis or before it began.

A credit rating is an opinion about the likelihood of default by a government and is based on (1) the perceived ability to service debt-a fiscal issue-and (2) the willingness of a government to service its debt-a non-fiscal issue. The measure of Polito and Wickens considers only the former. It is obtained by comparing the probability that forecasts of the future debt-GDP ratio over a given time horizon exceed a debt-GDP limit, and then mapping this probability into a credit rating using tables provided by Moody's. The problem not dissimilar to that of pricing an American option. The forecasts and their probability distributions are obtained using a time-varying vector autoregression based on the inter-temporal government budget constraint, but could be derived in other ways, if preferred. The debt limits reflect the maximum tax revenue capacity of an economy and are derived from an open-economy DSGE model with a Laffer curve from which labour tax revenues are maximised. Credit ratings obtained in this way are compared with those derived on the assumption of no change in tax policy. In this way the fiscal space available to an economy may be assessed. Full details may be found in Polito and Wickens (2015).

The debt-GDP limits are based on the inter-temporal government budget constraint. The government budget constraint expressed as a proportion of nominal GDP is

$$
\begin{aligned}
& \frac{d_{t}}{y_{t}}+\left(1+\rho_{t}\right) \frac{b_{t-1}}{y_{t-1}}=\frac{b_{t}}{y_{t}} \\
& d_{t}=g_{t}+z_{t}-v_{t} \\
& \rho_{t}=i_{t}^{b}-\pi_{t}-\gamma_{t} .
\end{aligned}
$$

where $y_{t}$ is real GDP, $d_{t}$ is the real primary deficit, $g_{t}$ is real government expenditures, $z_{t}$ is real transfers, $v_{t}$ is real tax revenues including seigniorage revenues, $\frac{b_{t}}{y_{t}}$ is the debt-GDP ratio, $\pi_{t}$ is the inflation rate, $\gamma_{t}$ is the rate of growth of GDP, $i_{t}^{b}$ is the nominal interest rate and $\rho_{t}$ may be interpreted as the effective discount rate after default adjusted for inflation. Solving forwards gives the intertemporal government budget constraint

$$
\frac{b_{t}}{y_{t}}=-E_{t} \sum_{j=1}^{\infty} \frac{\frac{g_{t+j}}{y_{t+j}}+\frac{z_{t+j}}{y_{t+j}}-\frac{v_{t+j}}{y_{t+j}},}{\prod_{s=1}^{j}\left(1+\rho_{t+s}\right)},
$$

The debt limits are obtained from forecasts of the variables on the right-hand side. They may be interpreted as the current level of debt that may be financed from future expected tax revenues $v_{t+s}$ given forecasts of the other variables. Two limits are of particular interest, IGBCL which uses forecasts of future tax revenues on the 
assumption of no change in policy rules, and FL which assumes that labour tax revenues are maximised using the DSGE model, see Davig et al. (2010, 2011).

Figure 9 shows the two debt limits and the actual debt-GDP ratio. In general, FL is not far above IGBCL, implying that there is not much room for additional taxes. The exceptions are Ireland, the Netherlands, Portugal, Spain and the UK, all of which have more fiscal space. The two debt limits lie above the actual debt-GDP ratio for all but two countries, implying that their fiscal stances are sustainable. Portugal after 2008 is an exception. Its debt-GDP ratio lies above IGBCL, implying that its fiscal stance is not sustainable under unchanged policy. But it lies below FL implying that its fiscal stance is sustainable under tax maximising policy. Significantly, Greece's debt-GDP ratio lies above both IGBCL and FL for the whole time that it has been in the eurozone and therefore has never had a sustainable fiscal stance over this period. A further implication of these findings is that Greece will be unable to meet its debt obligations in the future unless it takes more drastic fiscal actions such as reducing expenditures or raising sales taxes.

The probability of defaulting between period $t$ and $t+h$ given information up to period $t$, is given by

$$
p_{t, t+h}^{c}=\sum_{j=1}^{h} p_{t, t+j}
$$

where $p_{t, t+h}$ is the probability of defaulting in period $t+h$, but not before, is given by
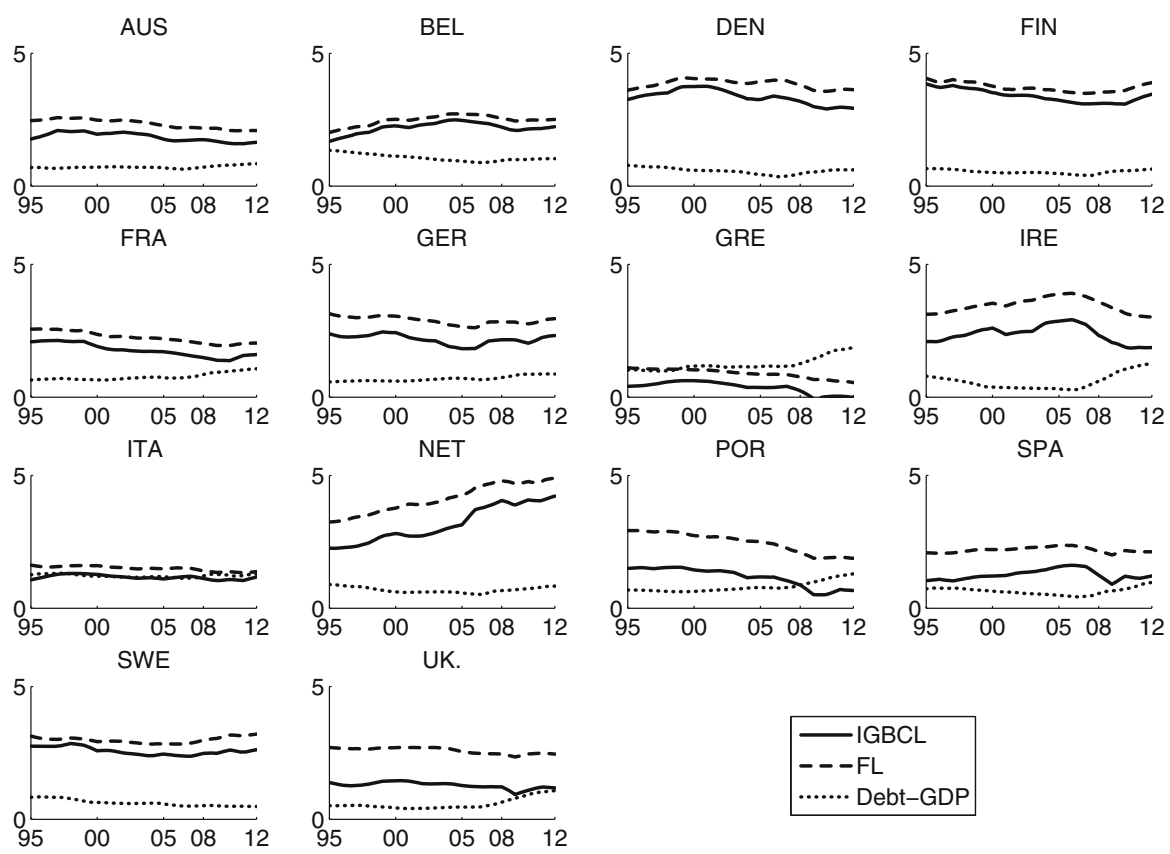

Fig. 9 IGBCL, FL limits and debt-GDP ratio 


$$
p_{t, t+h}=p_{t+h}\left(1-p_{t+h-1}\right)\left(1-p_{t+h-2}\right) \ldots\left(1-p_{t+1}\right)
$$

and $p_{t+h}$, the probability of defaulting in period $t+h$, is obtained by comparing the forecast of the debt-GDP ratio in period $t+h$ with the debt limit

AUS
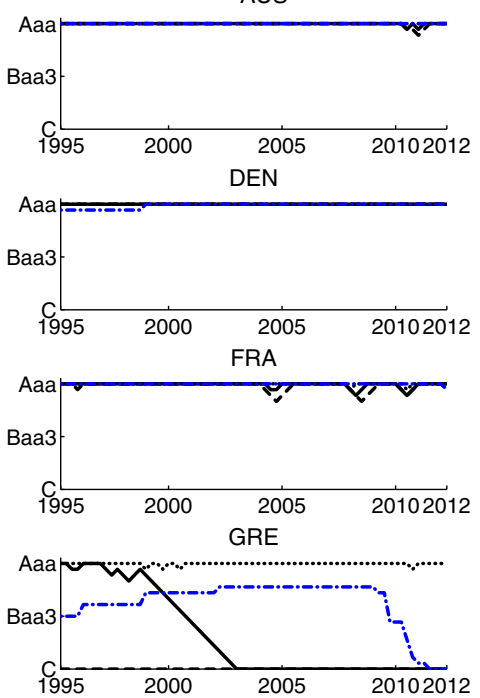

IRE
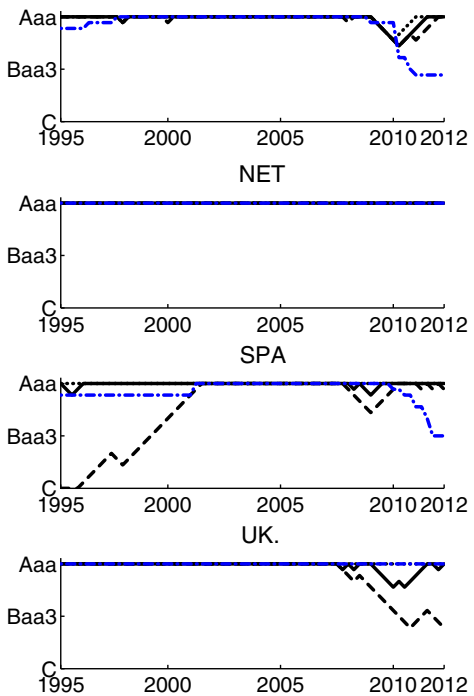

BEL
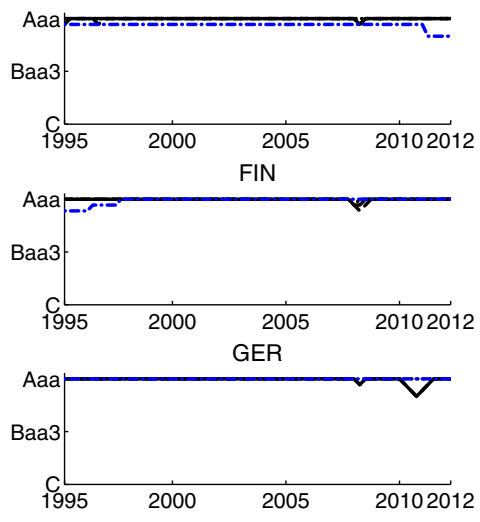

---IGBCL - FL …… MDL •-•-· historic

(a)

ITA
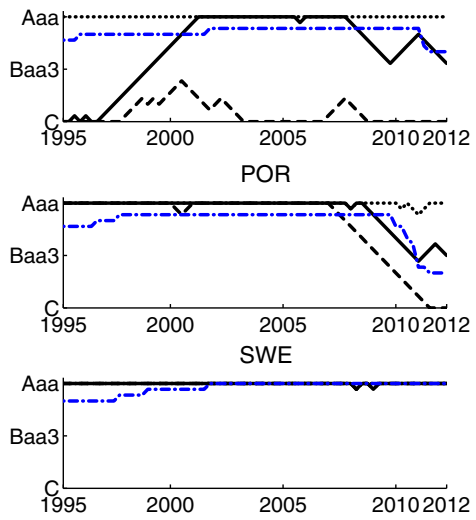

- - -IGBCL —FL ….... MDL .-.-·historic

(b)

Fig. 10 Credit ratings 


$$
p_{t+h}=\operatorname{Pr}\left(\frac{b_{t+h}}{y_{t+h}} \geq \overline{b_{t+h}} \mid \frac{b_{t}}{y_{t+h}}\right),
$$

where $\frac{\overline{b_{t+h}}}{y_{t+h}}$ denotes the debt limit, IGBCL, FL and MDL, which implausibly assumes no government expenditures, i.e. $g_{t}+z_{t}=0 . p_{t, t+h}^{c}$ is then mapped into a credit rating using tables from Moody's.

The alternative credit ratings for these countries for the period 1995-2012 based on these three different debt limits, together with the official credit rating, are shown in Fig. 10a, b. There are differences from the official ratings for all countries. For many countries the downgrades compared with the official ratings are small, and only emerge at the start of the financial crisis. Following the crisis, some countries are given an upgrade by the model-based credit ratings while the official ratings remained lowered. For the crisis countries, the downgrades are much larger and emerge prior to the crisis. Once again Greece is the main outlier; the model-based rating starts to downgrade Greece well before joining the euro and gives it a junkbond rating from 2003, which is before the official downgrade started in 2009.

These results suggest that it is possible to obtain credit ratings cheaply and independently of the official ratings and that these ratings identify potential problems with the fiscal stance earlier than the official ratings.

\section{Conclusions}

This paper has argued that the eurozone financial crisis was in large part the result of a common monetary policy not being suitable for individual countries. This created excessive private and public borrowing and a balance sheet recession in which expansionary monetary policy has had limited success. In this way, the limitations of monetary policy where there is a single currency and many independent fiscal jurisdictions has brought about high debt-GDP ratios and caused a fiscal crisis. The other side of the problem is that of countries with excessive current account surpluses. The financial markets failed to identify the crisis beforehand. The model of credit ratings presented would have identified and signalled to market participants signs of the impending European sovereign debt crisis well before 2010, when the official credit ratings first reacted to the crisis. This would have resulted in higher borrowing costs for the countries that over-borrowed due to negative real interest rates and may have helped prevent the crisis.

Greece is clearly a special case. Its debts are so large that there are severe doubts that they can be repaid if Greece stays in the euro. The credit ratings for Greece presented above suggest that its fiscal problems were evident well before Greece joined the euro and that it will be unable to repay its debt in full in the future.

The financial crisis has caused the ECB to extend its brief to fiscal matters in order to protect its loans to the banking system and to be able to carry out the lender of last resort function of a central bank. The extreme problems of Greece have prompted considerations of fundamental changes to governance in the eurozone: a banking union, a fiscal union and a political federation. 
Arguably, if credit risk were accurately assessed then the probability of default would be reflected in borrowing rates. In this way the market would automatically correct for the inherent and unavoidable limitations of eurozone monetary policy that has permitted countries to borrow at rates more suited to Germany. Changes to the governance of the eurozone designed to make monetary union sustainable might then be unnecessary.

Open Access This article is distributed under the terms of the Creative Commons Attribution 4.0 International License (http://creativecommons.org/licenses/by/4.0/), which permits unrestricted use, distribution, and reproduction in any medium, provided you give appropriate credit to the original author(s) and the source, provide a link to the Creative Commons license, and indicate if changes were made.

\section{References}

Curdia V, Woodford M (2008) Credit frictions and optimal monetary policy. National Bank of Belgium Working Paper Research no. 146

Davig T, Leeper EM, Walker TB (2010) Unfunded liabilities and uncertain fiscal financing. J Monet Econ 57:600-619

Davig T, Leeper EM, Walker TB (2011) Inflation and the fiscal limit. Eur Econ Rev 55:31-47

Gertler M, Kiyotaki N (2010) Financial intermediation and credit policy in business cycle analysis. In: Friedman BM, Woodford M (eds) Handbook of monetary economics, chap 3, vol 3. Elsevier, Amsterdam, pp 547-599

Koo RC (2011) The world in balance sheet recession: causes, cure, and politics. Real World Econ Rev (issue 58)

Polito V, Wickens MR (2011) Assessing the fiscal stance in the European Union and the United States, 1970-2011. Econ Policy 26:599-647

Polito V, Wickens MR (2012) A model-based indicator of the fiscal stance. Eur Econ Rev 56:526-551

Polito V, Wickens MR (2015) Sovereign credit ratings in the European Union: a model-based fiscal analysis. Eur Econ Rev 78:220-247

Wickens MR (2010) Some unpleasant consequences of the euro. Open Econ Rev 21:351-364 